\title{
Plasma and catalyst for the oxidation of NOx
}

\author{
Jögi, I.; Erme, K.; Levoll, E.; Raud, J.; Stamate, Eugen
}

Published in:

Proceedings of the XXXIII International Conference on Phenomena in Ionized Gases (ICPIG 2017)

Publication date:

2017

Document Version

Publisher's PDF, also known as Version of record

Link back to DTU Orbit

Citation (APA):

Jögi, I., Erme, K., Levoll, E., Raud, J., \& Stamate, E. (2017). Plasma and catalyst for the oxidation of NO . In Proceedings of the XXXIII International Conference on Phenomena in Ionized Gases (ICPIG 2017) (pp. 32). Instituto de Plasmas e Fusão Nuclear. http://icpig2017.tecnico.ulisboa.pt/

\section{General rights}

Copyright and moral rights for the publications made accessible in the public portal are retained by the authors and/or other copyright owners and it is a condition of accessing publications that users recognise and abide by the legal requirements associated with these rights.

- Users may download and print one copy of any publication from the public portal for the purpose of private study or research.

- You may not further distribute the material or use it for any profit-making activity or commercial gain

- You may freely distribute the URL identifying the publication in the public portal

If you believe that this document breaches copyright please contact us providing details, and we will remove access to the work immediately and investigate your claim 


\title{
Plasma and catalyst for the oxidation of $\mathrm{NO}_{\mathrm{x}}$
}

\author{
I. Jõgi ${ }^{1}$, K. Erme ${ }^{1}$, E. Levoll ${ }^{1}$, J. Raud ${ }^{1}$, E. Stamate ${ }^{2}$ \\ ${ }^{1}$ Institute of Physics, University of Tartu, Tartu, Estonia \\ ${ }^{2}$. Department of Energy Conversion and Storage, Technical University of Denmark, Roskilde, Denmark
}

\begin{abstract}
The removal of $\mathrm{NO}_{\mathrm{x}}$ from the exhaust gases requires the oxidation of most abundant $\mathrm{NO}$ to $\mathrm{NO}_{2}$ or $\mathrm{N}_{2} \mathrm{O}_{5}$. The oxidation can be done by non-thermal plasma but the efficiency is limited due to the back-reaction of $\mathrm{NO}_{2}$ to $\mathrm{NO}$ by $\mathrm{O}$ radicals. Present contribution investigates the role of catalysts in the improvement of oxidation efficiency based on the stationary and time-dependent studies of the $\mathrm{NO}_{\mathrm{x}}$ oxidation at different reactor configurations and experimental conditions. The plasma produced active oxygen species $\left(\mathrm{O}, \mathrm{O}_{3}\right)$ were shown to play an important role in the reactions taking place on the catalyst surfaces while the exact mechanism and extent of the effect depended on the reactor configuration. The effect of catalyst at different experimental conditions was quantitatively described with the aid of analytical lumped kinetic models derived for the $\mathrm{NO}_{\mathrm{x}}$ oxidation when the catalyst was directly in contact with plasma or only with the ozone.
\end{abstract}

\section{Introduction}

$\mathrm{NO}_{\mathrm{x}}\left(\mathrm{NO}, \mathrm{NO}_{2}\right)$ produced in the burning of fossil fuels is a major threat to the environment [1]. The available adsorption or absorption based $\mathrm{NO}_{\mathrm{x}}$ removal methods work efficiently when the most abundant $\mathrm{NO}_{\mathrm{x}}$ constituent $\mathrm{NO}$ is oxidized to $\mathrm{NO}_{2}$ or $\mathrm{N}_{2} \mathrm{O}_{5}$. The oxidation can be done by non-thermal plasmas which produce highly reactive oxygen species $\left(\mathrm{O}, \mathrm{OH}, \mathrm{O}_{3}\right)$. One of the main limiting factor for plasma oxidation of $\mathrm{NO}$ in $\mathrm{O}_{2}: \mathrm{N}_{2}$ mixtures is the back-reaction of $\mathrm{NO}_{2}$ to $\mathrm{NO}$ by $\mathrm{O}$ radicals [2]. The presence of such back-reaction distinguishes the $\mathrm{NO}_{\mathrm{x}}$ from organic compounds which are also often oxidized by plasma. The back-reaction can be suppressed by different means including the indirect treatment by ozone or the use of catalyst.

Present contribution investigates the role of catalyst in the plasma oxidation of $\mathrm{NO}_{\mathrm{x}}$. The investigation involved stationary and timedependent studies of $\mathrm{NO}_{\mathrm{x}}$ oxidation with different configurations of plasma and catalyst placement at varying experimental conditions. Furthermore, analytical lumped kinetic models incorporating effective reaction coefficients for $\mathrm{NO}_{\mathrm{x}}$ oxidation were derived to quantify the effect of catalyst at different experimental conditions $[3,4]$. The results were mostly obtained in dry $\mathrm{O}_{2}: \mathrm{N}_{2}$ mixtures.

\section{Main results}

Stationary and time-dependent experiments with different binary metal-oxides placed either directly in contact with plasma or after the active plasma zone demonstrated that the metal-oxides could act both as $\mathrm{NO}_{\mathrm{x}}$ adsorbents and oxidation catalysts.

With the catalyst directly in contact with the plasma, the back-reaction in gas phase remained important but the reaction balance was shifted towards the production of $\mathrm{NO}_{2}$. The time-dependent changes of the $\mathrm{NO}_{\mathrm{x}}$ concentrations suggested that the surface processes involved both the adsorption/disproportionation reactions of $\mathrm{NO}_{2}$ [5] and reactions with plasma produced oxygen species. The importance of the latter process was also emphasised by the production of $\mathrm{NO}_{2}$ on the catalyst surfaces previously treated by oxygen discharge.

The back-reaction can be avoided when the plasma is used indirectly for the production of ozone which then reacts with $\mathrm{NO}_{x}$. In this configuration the catalyst enhanced considerably the oxidation of $\mathrm{NO}_{2}$ to $\mathrm{N}_{2} \mathrm{O}_{5}$ [3]. The surface processes involved the decomposition of $\mathrm{O}_{3}$ to surface bound oxygen species which then aided the oxidation of $\mathrm{NO}_{2}$ to $\mathrm{NO}_{3}$. Subsequent formation of $\mathrm{N}_{2} \mathrm{O}_{5}$ on the surface resulted also in the increased $\mathrm{NO}_{\mathrm{x}}$ adsorption ability of tested metal-oxides.

\section{Acknowledgements}

The study was partially financed by Estonian Research Council (Grant nr. 585).

\section{References}

[1] K. Skalska, J.S. Miller, S. Ledakowicz, Sci. Total. Environ. 408 (2010) 3976.

[2] I. Jõgi, E. Levoll, J. Raud, Chem. Eng. J. 301 (2016) 149.

[3] I Jõgi, K. Erme, J. Raud, M. Laan, Fuel 173 (2016) 45.

[4] I. Jõgi, E. Levoll, J. Raud, Catal. Lett. 147 (2017) 566.

[5] L. Sivachandiran, F. Thevenet, P. Gravejat, A. Rousseau, Appl. Catal. B: Environ. 142 (2013) 196. 